\title{
Eco-Preferences and Actors Behind: Case Study on Academic Community in Lithuania
}

\author{
Renata Dagiliūtè ${ }^{1^{*}}$, Rasa Paulauskaitè ${ }^{1}$ \\ ${ }^{1}$ Department of Environmental Sciences, Vytautas Magnus University, Kaunas LT-44404, Lithuania \\ *Corresponding author: r.dagiliute@gmf.vdu.lt \\ cross'ref http://dx.doi.org/10.5755/j01.erem.63.3.4801
}

(Received in April, 2013; accepted in September, 2013)

\begin{abstract}
Consumption induces various environmental impacts, therefore change of consumption patterns, and decrease in related environmental burden are key issues of sustainable consumption. Promotion of environment friendly local products is related with willingness to pay for such products and factors behind. This paper examines willingness to pay and preferences within product attributes like price, quality and origin of young consumers in Lithuania. Survey results reveal that the majority of respondents are willing to buy environmentally friendly products, but in some cases the price might negatively influence consumer decision. Particular product analysis has shown that if not environment friendly then local products have preference. Nevertheless, results also indicate the need for further improvement in the education of academic community on the impact of goods and services on the environment. Revising the content of the study programmes and inner sustainability policies of universities could be the options for the improvement in this field and in sustainability in general.
\end{abstract}

Keywords: sustainable consumption, eco-friendly products, willingness to pay, factors, higher education

\section{Introduction}

Today consumption is not only satisfaction of needs. Consumption forms the personal identity and expresses the person's place in the world (Černevičiūtè 2006). However, consumption related environmental impacts challenge sustainable development in general.

Different goods and services have an impact on the environment throughout the whole life-cycle. The Environmental Impact of Products (EIPRO) study identified four areas having the greatest impact (EC 2006): food and drink, private transport and mobility, housing, tourism. According to the life-cycle analysis, food and beverage consumption was found to be responsible for around 20-30\% of environmental impacts in most impact categories caused by consumption in the EU (JRC/IPTS 2008). The second biggest consumption area that has impact on the environment is transport and mobility. Direct emissions from the combustion of fuels make up about $77 \%$ of the total life-cycle based GHG emissions from passenger car transport (JRC/IPTS 2008). The next area is housing. Housing has multiple impacts on the environment throughout its life-cycle. Housing is estimated to cause $38 \%$ of $\mathrm{GHG}$ emissions, $22 \%$ of acidifying emissions, $32 \%$ of tropospheric ozone precursors and 38\% of material resource use activated by national consumption (EEA and ETC/SCP 2010).

Reshaping of consumption patterns and decrease in related environmental impacts are key issues for sustainable consumption. One of the first definitions of the sustainable consumption was coined in Oslo in 1994 in line with the Brundtland commission definition of "sustainable development": "Sustainable consumption is the use of goods and services that respond to basic needs and bring a better quality of 
life, while minimizing the use of natural resources, toxic materials and emissions of waste and pollutants over the life cycle, so as not to jeopardize the needs of future generations" (UNEP 2010). The World Summit on Sustainable Development in Johannesburg in 2002 placed the concept of "sustainable consumption" firmly on the policy map and "changing consumption and production patterns" had been identified as one of three overarching objectives for sustainable development (UN 2002). The United Nations Conference on Sustainable Development "Rio +20 " in 2012 approved a common report "The Future We Want" and the 10-year framework of programmes (10YFP) on sustainable consumption and production patterns were adopted (UN 2012).

Hence, the consumption impact on the environment depends on the intensity of consumption and consumer behaviour and factors behind. As an alternative to reduce the impact on the environment could be environmental friendly goods and services consumption. In any context, there are alternative discourses that surround alternative forms of green (sustainable) buying, which might pertain to a range of activities, from purchasing fairly traded goods to buying organic good. In some cases, these behaviours appear to be in conflict; e.g. buying local good to support local producers (Gilg, Barr et al. 2005). Despite that, recently growing environmental awareness induces changing consumers' behaviour. Such behaviour changes have fostered many companies to offer the environmentally friendly products that do less damage on the environment (Lynikaite, Liesionis 2010). Consumers' attentiveness to the environmental problems has led for environmentally friendly products purchase and consumption (Mazar, Zhong 2010). However, depending on product attributes and various factors, willingness to pay and consume such goods and services can vary.

Different external and internal factors result in consumption of goods and services (Stankevičienè 2005; Streimikienè et al. 2011). The external factors could be illustrated as culture, society class, impact on the group and family and the internal (or personal) factors could be classified as motivation, perception, knowledge, attitudes, personality, lifestyle and other determinants. As indicated by Sian et al. (2010) culture, acting consumers' lifestyle and values, has a significant impact on consumption. Usually, the cross-cultural society evaluates individual goods and services differently. Society class is also considered one of the factors as it often defines the status of individuals' material condition in society. Research shows that consumers who feel greater material deprivation were not ready to choose environment friendly goods and services (Leonavičius 2002). Family is another most influential factor to choose environmentally friendly products as studies show (Skulskis, Girgždiené 2009; Hjelmar 2011). Personal factors also play a crucial role. As indicated by Niaura (2013), stronger environment friendly attitudes are more often reflected in behavioural intentions.
There are also context and demographical factors influencing both consumption intention and behaviour (Zhu et al. 2013). Hence, price, income, age, gender, occupation and other socio-economic factors also determine consumption. Results of the works of Brécard et al. (2009) and Brouhle and Khanna (2012), Gan, et al. (2008) show that education, gender and age play a significant role in the respondents' decision to choose eco-friendly products. Kriwy and Mecking (2012) have indicated that German consumers with higher education are more often likely to be green consumers. Lockie et al. (2004) found gender as a strongly affecting factor for organic food consumption. Srinivisan and Blomquist (2009) estimated that probability of purchasing ecolabelled paper towels decreases with the age. Hence, the indicated and other studies by Rutkoviene and Garliauskiene (2007), Park and Ha (2012) reveal that the factors like attitude, social and personal norms, income, family, principles, education, gender etc could be important in promoting environmental friendly goods and services in general. Nevertheless, clear distinction within the factor groups is rather difficult, as these factors interact and influence directly or indirectly green consumption (Zhu et al. 2013).

Recent Eurobarometer (2013) study shows that in Lithuania knowledge of environment friendly products has significantly increased, however, still 32 $\%$ of the citizens of Lithuania know little about environmental impacts of the products they buy and use, $6 \%$ know nothing. Only $28 \%$ buy eco-labelled products and price is a dominating factor when making purchasing decision.

Young and educated people are usually seen as most active and environmentally aware (Tan, Lau 2009, Brécard et al. 2009, Kriwi and Mecking 2012). On the other hand, Brazienė and Butkevičienė (2009) in their study have found out that consumer culture is rather strong within students' population in Lithuania. $59.7 \%$ of the respondents in their leisure time would choose visiting shopping malls. Consequently, the aim of our research is to clarify the willingness to buy and use environment friendly goods and services within the communities of some Lithuanian universities and to determine main factors influencing the purchasing decision.

The paper is structured as follows. First, we present perceptions and willingness to pay for environment friendly products. Then preferences in origin and quality and particular products are discussed. The next section presents main factors determining the willingness to choose eco-products. Finally, results are discussed and conclusions are drawn.

\section{Methods}

As already indicated, young and educated people are more active and environmentally aware. In addition, young people and people with higher education are usually more susceptible to innovations 
and they are more interested in the environment and, correspondingly, they are those shaping the consumption in the future (Vermeir, Verbeke 2008). Thus, it is important to evaluate their intention to choose and willingness to pay more for environment friendly products (goods and services), as well as to define main factors for more sustainable consumption. In this paper environment friendly (eco-) products denote both goods and services. Most of the other studies concentrate on particular goods, but in our research we have included several types of goods ranging from food to clothes and some services. Though different factors may influence the choice and purchase of different goods and services, generalized results would be of interest for consumption policy and decision making.
The survey of students and employees of some universities in Lithuania was carried out in 2011-2012 (December - February). The questionnaire was constructed by the authors and was based on 28 closed and dichotomous types of questions. Having a small-scale survey, the method of stochastic quota sampling was chosen for the survey (Kardelis, Sapagovas 1998). Respondents filled out questionnaires online. Depending on the availability, the link to the survey was distributed via the universities' intranet, public forums and social networks of universities in Lithuania. There was a total of 396 respondents. The respondents' profile is presented in Table 1 . In total, $79.8 \%$ of respondents were students, females were dominating.

Table 1. Profile of the respondents

\begin{tabular}{|c|c|c|c|c|c|}
\hline $\begin{array}{l}\text { Socio-economic } \\
\text { characteristics }\end{array}$ & Frequency & $\%$ & $\begin{array}{l}\text { Socio-economic } \\
\text { characteristics }\end{array}$ & Frequency & $\%$ \\
\hline Gender & & & Accommodation & & \\
\hline Female & 315 & 79.5 & Dormitory & 49 & 12.4 \\
\hline Male & 81 & 20.5 & Apartment & 252 & 63.6 \\
\hline Age & & & Private house & 92 & 23.2 \\
\hline $18-25$ & 332 & 83.8 & Other & 3 & 0.8 \\
\hline $26-33$ & 41 & 10.4 & Income & & \\
\hline $34-41$ & 10 & 2.5 & Up to 500 & 101 & 25.5 \\
\hline 42 and above & 13 & 3.3 & $501-1000$ & 173 & 43.7 \\
\hline Education & & & $1001-1500$ & 83 & 21 \\
\hline Basic/ Secondary & 167 & 42.2 & 1500 or more & 39 & 9.8 \\
\hline Vocational/College & 10 & 2.5 & \multirow{3}{*}{ Social status } & & \\
\hline Higher & 219 & 55.3 & & & \\
\hline Residence & & & & & \\
\hline City & 336 & 84.8 & Wealthy & 32 & 8.1 \\
\hline Town & 35 & 8.8 & Average living & 263 & 66.4 \\
\hline Township & 10 & 2.5 & Needy & 101 & 25.5 \\
\hline Village & 15 & 3.8 & Study/work place & & \\
\hline Children under six & & & VMU & 253 & 63.9 \\
\hline Yes & 26 & 6.6 & Other & 143 & 36.1 \\
\hline No & 370 & 93.4 & & & \\
\hline
\end{tabular}

Statistical analysis was based on descriptive statistics, binomial test and regression analysis. Binary probit regression was used to evaluate the factors, which influenced the respondents' decision. Regression was considered statistically significant at the maximum likelihood chi-square p-value less than 0.05 . To see whether a certain group of products or services were chosen more often than the other, binomial test was applied, assuming that all groups of products and services had the same probability to be chosen $(50 \%)$. Then choosing within different product attribute groups, respondents were provided with product or service characteristics like the origin (Lithuanian, imported), production type (conventional, ecological) and price (in some cases). We have chosen these attributes as we consider them most influential. For example, Govindasamy and Puduri (2010) state that respondents are willing to buy locally grown produce and results of Gan et al. (2008) show that more than $74 \%$ of the respondents purchase green (environment friendly) products, however, price is a dominant factor then purchasing (Eurobarometer 2013).

Price was indicated for Lithuanian eco-product, Lithuanian conventional product, imported eco and conventional products based on market prices within the research period. Though eco-products not necessarily should be more expensive, price of ecoproducts was higher than that of conventional ones despite the origin of the product. Price difference varied from $20 \%$ to approximately 3 times. Certain products were chosen depending on their availability on the market, especially regarding their origin. As supply of environment friendly services is rather limited in Lithuania, prices were set more on the hypothetical basis.

Regression analysis included the factors whose importance for their personal consumption was evaluated by the respondents (friends, family, colleagues, personal attitude, social status, inhabitation, advertisement, lifestyle, religion, traditions) and socio economic factors (age, occupation, and gender, and income, children under 
six, membership in some organization and some other). More or less, these factors cover external factors, internal (personal) factors, context and demographical variables consumption factors (Stankevičienè 2005, Tanner, Kast 2008, Zhu et al. 2013).

Most of the factors are determined in conformity with subjective consumers' evaluation, as they were asked whether one or other factors influence their purchase. This approach and the fact the majority of respondents were women; limit to some extent the results of the research. Nevertheless, this research provides some insights about possible important factors for the choice of a specific group of consumers.

\section{Results}

\subsection{Perception about environmentally friendly goods and services and willingness to pay}

Before analysing consumers' willingness to pay premium price for environment friendly goods and services, it is necessary to ascertain whether consumers know environment friendly products as such. The results of the research show that the majority of respondents $(82.3 \%)$ are aware of environment friendly goods and services.

$89.9 \%$ of respondents have attributed environmental issues to the eco-products (Table 2).

Table 2. The respondents' opinion on the attributes of environment friendly products (goods and services)

\begin{tabular}{||l|l|l||}
\hline \hline Attribute & Frequency & $\mathbf{\%}$ \\
\hline Safe for environment & 356 & 89.9 \\
\hline Not harmful for health & 277 & 69.9 \\
\hline Made only in Lithuania & 13 & 3.3 \\
\hline Has eco-certification & 214 & 54 \\
\hline Other & 15 & 3.8 \\
\hline
\end{tabular}

The less part of respondents $(69.9 \%)$ think that these products should be safe for health. $54 \%$ of respondents think that these goods and services should be identified with eco-certification. The least part of respondents think that goods and services that are made in Lithuania are environment friendly ones. This reveals that the majority of respondents attribute environmental and health issues to the ecological products, but relatively fewer respondents identify the main attribute of the ecological product, namely, a certified eco-label.

The majority of respondents $(83.6 \%)$ buy environment friendly goods and services only sometimes or seldom. $11.6 \%$ of respondents buy these products always or often. Only a small percentage of respondents $(4.8 \%)$ do not buy such goods and services at all.

Results of the study show that the majority of respondents are willing to pay higher price for environmentally friendly goods and services: $37.6 \%$ of the interviewed respondents are willing to pay 5$10 \%$ higher premium price. $30.8 \%$ of respondents are willing to pay up to $5 \%$ premium price. And only $2.5 \%$ of respondents are willing to pay higher than $21 \%$ premium price (Table 3 ).

Table 3. Willingness to pay (WTP) premium price for environment friendly goods and services

\begin{tabular}{||l|l|l||}
\hline WTP & Frequency & \% \\
\hline $0 \%$ & 31 & 7.8 \\
\hline Up to $5 \%$ & 122 & 30.8 \\
\hline $5-10 \%$ & 149 & 37.6 \\
\hline $11-15 \%$ & 56 & 14.1 \\
\hline $16-20 \%$ & 28 & 7.1 \\
\hline$>21 \%$ & 10 & 2.5 \\
\hline
\end{tabular}

\subsection{Consumers' preferences over a certain product attribute}

Results of the analysis which product from the group (conventional Lithuanian, ecological Lithuanian, ecological imported and conventional imported) would be chosen by respondents are presented in Figure 1.

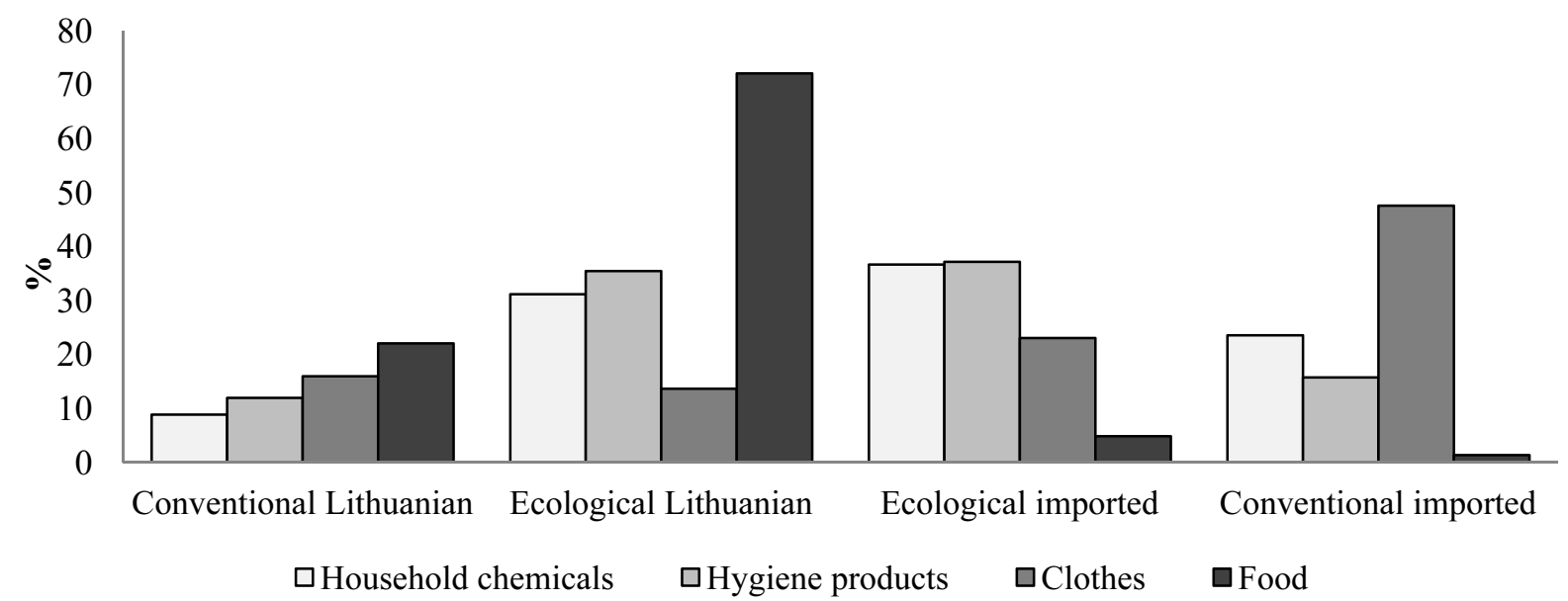

Fig. 1. Choice of goods depending on the origin and quality 
$94 \%$ of respondents were willing to choose locally made Lithuanian food $(\mathrm{p}<0.001)$. The majority of respondents $(72 \%)$ are willing to choose the Lithuanian organic food. There is no statistically significant difference between chosen Lithuanian hygiene products and imported hygiene products $(\mathrm{p}=$ $0.291)$. However, bigger part of respondents $(72.5 \%)$ is willing to choose ecological hygiene products. Then, analysing the influence of the origin of household chemicals and clothes, Lithuanian origin was not given the preference. $60.1 \%$ of respondents are willing to choose imported household chemistry $(\mathrm{p}<0.001)$ and $70.5 \%$ of respondents are willing to choose imported clothes $(\mathrm{p}<0.001)$. If in the case of household chemicals eco-friendly products were given the preference, in the case of clothes conventional clothes rather than eco clothes were preferred more often.

Within given conventional and environment friendly services, beauty $(57.8 \%)$ and transport services $(59.8 \%)$ were dominant ones. Environment friendly services of premises cleaning and reconstruction and construction were given less preference. Some respondents stated they would choose no environment friendly services, some of them did not know that such services existed.

As very often it is declared that eco-products are expensive and not affordable, to analyse whether price has an influence on the preference of eco-products and services, we add prices to certain products. Results reveal that within food products Lithuanian eco-labelled yoghurt $\quad(57.3 \%), \quad$ Lithuanian conventional milk $(61.1 \%)$ were given the preference, and with a chocolate choice conventional both Lithuanian (49\%) and imported (36.9\%) dominated (Table 4).

Within non-food products, one could notice the tendency to choose and pay more for environment friendly goods in the case of hair shampoo, face cream, but not for tricot, dishwasher or window cleaner. Nevertheless, in the latter case Lithuanian products were given priority.

Respondents' choices also indicated that price was not a limiting factor for consumption and people did not always tend to buy only the cheapest products. For example, imported yoghurt and milk both ecolabelled and conventional were cheaper than Lithuanian ones, but not given the preference. Ecolabelled hair shampoo was more expensive than conventional one, but was given the priority. These two examples indicate willingness to pay for ecolabelled products, but not in the case of chocolate, tricot, window cleaner and dishwasher. The latter might be influenced by the price (which was twice and more higher for eco-product than a conventional one) as well as be affected by other product attributes and factors like e.g. health related perceptions.

Though prices for environment friendly services were also higher than conventional ones, respondents tend to choose the first ones. However, only in the case of building and renovation services significant differences were estimated $(\mathrm{p}<0.05)$.

Table 4. Choice within product attributes

\begin{tabular}{|c|c|c|c|c|c|}
\hline Product & $\begin{array}{c}\text { Lithuanian } \\
\text { conventional } \\
\text { (priced) }\end{array}$ & $\begin{array}{c}\text { Imported } \\
\text { conventional } \\
\text { (priced) }\end{array}$ & $\begin{array}{l}\text { Lithuanian eco- } \\
\text { labelled (priced) }\end{array}$ & $\begin{array}{l}\text { Imported eco- } \\
\text { labelled } \\
\text { (priced) }\end{array}$ & Binomial test \\
\hline Yogurt & $18.9 \%$ & $4.5 \%$ & $57.3 \%$ & $19.2 \%$ & $<0.001 *$ \\
\hline Milk & $61.1 \%$ & $8.3 \%$ & $17.2 \%$ & $13.4 \%$ & $<0.001$ \\
\hline Chocolate & $49.0 \%$ & $36.9 \%$ & $11.1 \%$ & $3.0 \%$ & $<0.001$ \\
\hline Tricot & $28.5 \%$ & $37.9 \%$ & $13.4 \%$ & $20.2 \%$ & $<0.001$ \\
\hline Hair shampoo & $9.6 \%$ & $17.7 \%$ & $43.7 \%$ & $29.0 \%$ & $<0.001$ \\
\hline Soap & $27.0 \%$ & $23.2 \%$ & $37.4 \%$ & $12.4 \%$ & 0.960 \\
\hline Face cream & $11.4 \%$ & $12.9 \%$ & $43.9 \%$ & $31.8 \%$ & $<0.001$ \\
\hline Window cleaner & $37.9 \%$ & $26.8 \%$ & $26.3 \%$ & $9.1 \%$ & $<0.001$ \\
\hline Dish washer & $28.0 \%$ & $26.0 \%$ & $28.5 \%$ & $17.4 \%$ & 0.119 \\
\hline Services & \multicolumn{2}{|c|}{ Eco-friendly (priced) } & \multicolumn{2}{|c|}{ Conventional (priced) } & \\
\hline $\begin{array}{l}\text { Reconstruction and } \\
\text { construction }\end{array}$ & \multicolumn{2}{|c|}{$55.8 \%$} & \multicolumn{2}{|c|}{$44.2 \%$} & 0.024 \\
\hline Premise cleaning & \multicolumn{2}{|c|}{$52.8 \%$} & \multicolumn{2}{|c|}{$47.2 \%$} & 0.291 \\
\hline Beauty services & \multicolumn{2}{|c|}{$51.5 \%$} & \multicolumn{2}{|c|}{$48.5 \%$} & 0.580 \\
\hline
\end{tabular}

*bold values $\mathrm{p}<0.05$

\subsection{Factors determining the purchasing and willingness to pay for environment friendly goods and services}

Consumption is influenced by the factors, which are directly or indirectly related with consumers' decision to choose one or any other product. As to the influence of the price, origin and quality factors, we have studied which other factors do influence consumers to choose goods and services (Table 5). $73.7 \%$ of respondents answered that their personal attitude is the most important in the choice of products. Lifestyle (40.2\%) and family (24\%) were factors, which also have had the most significant influence on the choice of products. Friends, colleagues, residence, advertisement, traditions and religion do the least influence on the respondents, as they claim. This indicates that the internal (individual) factors (personal attitude, lifestyle) influence consumers to choose certain products more than the external and context ones. 
Table 5. Factors which influence respondents' decision to choose products

\begin{tabular}{|l|l|l|l|l|l|l|}
\hline \multirow{2}{*}{ Factors } & Not important & Relatively important & \multicolumn{2}{l|}{ Important } \\
\cline { 2 - 7 } & Frequency & $\mathbf{\%}$ & Frequency & $\mathbf{\%}$ & Frequency & \% \\
\hline Friends & 228 & 57.6 & 152 & 38.4 & 16 & 4 \\
\hline Family & 118 & 29.8 & 183 & 46.2 & 95 & 24 \\
\hline Colleagues & 288 & 72.7 & 99 & 25 & 9 & 2.3 \\
\hline Personal attitude & 25 & 6.3 & 79 & 19.9 & 292 & 73.7 \\
\hline Social status & 220 & 55.5 & 121 & 30.6 & 55 & 13.9 \\
\hline Residence & 244 & 61.6 & 119 & 30.1 & 33 & 8.3 \\
\hline Advertisement & 269 & 68 & 115 & 29 & 12 & 3 \\
\hline Lifestyle & 63 & 15.9 & 174 & 43.9 & 159 & 40.2 \\
\hline Religion & 364 & 91.9 & 22 & 5.6 & 10 & 2.5 \\
\hline Traditions & 285 & 71.9 & 93 & 23.5 & 18 & 4.5 \\
\hline
\end{tabular}

To reveal that factors behind the price, origin and environment friendliness do have influence on the decisions to pay more and to buy environmental friendly goods or services, we have applied binary probit regression. Analysis has shown that the respondents' decision to buy environment friendly goods and services depends on knowledge, position in society according to the available income, education and friends (Table 6).

Table 6. Factors for buying environmentally friendly goods and services (regression results)

\begin{tabular}{||l|c|c|c||}
\hline \multirow{2}{*}{ Factors } & \multicolumn{3}{|c|}{ Statistics* } \\
\cline { 2 - 4 } (Intercept) & Wald Chi-Square & $\mathrm{B}$ & $\mathrm{p}$ \\
\hline Social status & 2.459 & -0.349 & 0.117 \\
\hline Friends & $\mathbf{1 1 . 2 8 2}$ & $\mathbf{0 . 5 9 7}$ & $\mathbf{0 . 0 0 4}$ \\
\hline Family & $\mathbf{5 . 9 4 8}$ & $\mathbf{0 . 4 4 2}$ & $\mathbf{0 . 0 1 5}$ \\
\hline Children under six & 0.176 & -0.078 & 0.675 \\
\hline Membership & 0.061 & -0.078 & 0.805 \\
\hline Collaborators/colleagues & 0.105 & 0.068 & 0.745 \\
\hline Knowledge & 0.059 & -0.046 & 0.808 \\
\hline Education & $\mathbf{1 5 . 4 5 3}$ & $\mathbf{0 . 7 3 5}$ & $<\mathbf{0 . 0 0 1}$ \\
\hline Income & $\mathbf{6 . 8 3 2}$ & $\mathbf{0 . 3 7 6}$ & $\mathbf{0 . 0 3 3}$ \\
\hline Age & 2.667 & -0.515 & 0.263 \\
\hline Gender & 0.270 & -0.184 & 0.966 \\
\hline Accommodation & 0.116 & -0.063 & 0.733 \\
\hline Personal attitude & 0.437 & -0.129 & 0.509 \\
\hline Residence & 0.257 & 0.165 & 0.612 \\
\hline Advertisement & 0.886 & 0.213 & 0.829 \\
\hline Study/work place & 1.062 & -0.153 & 0.303 \\
\hline Tradition & 0.830 & 0.141 & 0.362 \\
\hline Religion & 0.992 & 0.172 & 0.319 \\
\hline \hline
\end{tabular}

$* \mathrm{LR}=54.257, \mathrm{p}<0.05$.

As can be seen from the results, respondents' knowledge of environmentally friendly goods and services has been mostly influencing the willingness to choose such products $(\mathrm{B}=0.735, \mathrm{p}<0.05)$. Respondents, who have known about environment friendly products, are willing to choose and pay premium price more often than the unaware ones. Respondents who attribute themselves to wealthy or middle class, are also more likely to choose and pay for environmentally friendly products than those who attribute themselves to the needy group of society (B $=0.597, \mathrm{p}<0.05)$.

The factors of education $(\mathrm{B}=0.376, \mathrm{p}<0.05)$ and friends $(\mathrm{B}=0.442, \mathrm{p}<0.05)$ also have a significant influence on the willingness to choose environmentally friendly products (goods and services). Academically educated respondents are more willing to choose environment friendly products. The respondents, to whom the opinion of their friends is important in the choice of products, are willing to buy environmentally friendly products more than those whom the opinion of their friends is not so important.

\section{Discussion and conclusions}

Research results reveal rather positive trends in purchasing environmental goods and services in some cases and correspond to those in some other studies of consumer preferences. Our study has shown a relatively high awareness of young consumers about environment friendly products (goods and services). The majority of respondents in our study consider environment friendly products first to be safe for the environment and health. Ureña et al. (2008) presented some similar results in the Spanish case. The analysis of Stašys and Tarasevičius (2010) has shown that 
ecological products (especially organic food) are perceived by consumers as healthy, safe, local and with certificate. In our case only $54 \%$ of respondents indicated eco-products as eco-labelled ones, hence, the information provision and awareness rising still remain one of the tools for promotion of environment friendly products.

In general, respondents are willing to buy environmentally friendly products and are willing to pay premium price for environment friendly products. We have found that more than $91 \%$ of respondents are willing to pay premium price for environment friendly products. Bigger part of respondents $(37.6 \%)$ would like to pay between $5-10 \%$ of premium price. Usually, quality and origin plays an important role in the choice of the food products. We have found that the majority of respondents (94\%) are willing to choose Lithuanian food and $72 \%$ - Lithuanian organic food. However, when discussing other groups of products, neither local nor eco-products were given preferences, and only in the case of hygiene products, eco-products were dominating in our case. We assume this difference within choices could be explained by rather significant direct allocation of health issues to the food and the food quality.

When the price was added to the origin and quality of the product and certain products were analysed, eco-labelled food products not always were given the preference. In general, respondents were willing to pay for green products and services; however, this feature was case sensitive. When the price difference was twice or more higher, the price and locality were dominating attributes of the product. On the other hand, choice of particular products has revealed that instead of declared $5-10 \%$ of willingness to pay, respondents are ready to pay 20 $40 \%$ more for some eco-products. Though the price is rather often mentioned as a very important factor in consumption (Brécard et al. 2009), the price of green products is not the main factor in consumer's choice (Tanner and Kast 2003, Lin, Huang 2012), as the consumption is determined by various other consumption values.

As reviewed in the introduction, the factors like age, family, income and other socio-economic variables exert a relatively considerable influence on the choice of environment friendly products. Our research corresponds with some of the results, indicating a positive influence of knowledge, education as well as the status and friends on purchasing eco-products. Respondents who have knowledge of environment friendly goods and services are willing to choose these products more than those who do not know about them. Also, respondents with higher education and from wealthier layers of society are more willing to purchase environment friendly goods and services. The respondents, who appreciate their friends' opinion in the choice of purchases, are willing to buy ecoproducts more often than those to whom the opinion of their friends is not so important. However, the age is not a significant factor due to a rather uniform sample regarding the age in our case. Also the family is not important as most of the students, as we assume, are single and live separately from their parents, or possibly do not recognize, or are not willing to recognize the influence of the family. The studies of Ureña et al. (2008) and Lockie et al (2004) show that women and men differ in consumption and willingness to pay for organic food, in our case the gender is an irrelevant factor for choosing environment friendly goods and services. In our case, rather a big share of the women in the survey could influence this.

As the analysis of factors is mostly based on socio-economic variables and consumers' personal perceptions on determinants for purchasing environment friendly good and services, deeper analysis of the actual influence of internal and external factors would be beneficial. Also, an attitude - action gap should be addressed, as despite expressed knowledge, most of the respondents only sometimes or seldom reflect this knowledge in their environment friendly behaviour (Kollmuss, Agyeman 2002). Nevertheless, some insights for the supply and consumption policy could be gained from this study, especially regarding the origin and environmental attributes of the products.

Results also indicate the need for a further improvement in the education of young consumers and academic community in general about the impact of goods and services on the environment. This means that so far the efforts to increase environmental consciousness are inadequate and the environment and sustainability related courses should be included in the study programmes, or at least some topics should be covered in particular courses at university level for students in all study programmes. Though this study focuses only on purchasing behaviour, results could be generally beneficial for the shaping and innovating inner environmental and sustainability policies and actions in universities.

\section{References}

Brazienè R., Butkevičienė E. Attitudes of Lithuania students towards consumption. Philosophy. Sociology, 2009, Vol. 20, No. 4. p. 354-364.

Brécard Hlaimi B., Lucas S., Perraudeau Y., Salladarré F. D. Determinants of demand for green products: An application to eco-label demand for fish in Europe. Ecological Economics, 2009, Vol. 69, No. 1. p. 115-125. http://dx.doi.org/10.1016/j.ecolecon.2009.07.017

Brouhle K., Khanna M. Determinants of participation versus consumption in the Nordic Swan eco-labelled market. Ecological Economics, 2012, Vol. 73. p. 142-151. http://dx.doi.org/10.1016/j.ecolecon.2011.10.011

Černevičiūtè J. Consumption, identity and lifestyle [in Lithuanian]. Philosophy. Sociology, 2006, Vol. 3. p. 20-24.

ETC/SCP. 2010. Country Fact sheet on SCP policies for the UK. European Topic Centre for Sustainable Consumption and Production, Copenhagen. 
Eurobarometer. 2013. Attitudes of Europeans towards Building the Single Market for Green Products. Report, Flash Eurobarometer 367, July, 2013. URL: http://ec.europa.eu/public_opinion/flash/f1_367_en.pdf

European Commission. 2006. Environmental Impact of Products (EIPRO). Analysis of the cycle environmental impacts related to the final consumption of the EU-25. Main report. IPTS/ESTO Project, pp. 139.

Gan C., Wee H. Y., Ozanne L., Kao T. H. Consumers' purchasing behaviour towards green products in New Zealand. Innovative Marketing, 2008, Vol. 4, No. 1. p. 93102.

Gilg A., Barr S., Ford N. Green consumption or sustainable lifestyles? Identifying the sustainable consumer. Futures, 2005, $37 . \quad$ p. 481-504. http://dx.doi.org/10.1016/j.futures.2004.10.016

Govindasamy R., Puduri V. S. Hispanic consumers' perceptions toward locally grown ethnic produce: A study from the east-coast US. Renewable Agriculture and Food Systems, 2010, Vol. 26, No. 1. p. 38-45. http://dx.doi.org/10.1017/S1742170510000414

Hjelmar U. Consumers' purchase of organic food products. A matter of convenience and reflexive practices. Appetite, 2011, Vol. 56. No. 2. p. 336-344. http://dx.doi.org/10.1016/j.appet.2010.12.019

JRC/IPTS. 2008. Environmental improvement potentials of meat and dairy products. European Commission Joint Research Centre scientific and technical reports JRC Scientific and Technical Reports, EUR 23491 EM.

Kardelis K., Sapagovas J. Methodological aspects of a sample in social science studies [in Lithuanian]. Sociology, 1998, Vol. 4, No. 17. p. 35-39.

Kollmuss A, Agyeman J. Mind the Gap: why do people act environmentally and what are the barriers to proenvironmental behaviour? Environmental Education Research, 2002, Vol. 8, No. 3. p. 239-260. http://dx.doi.org/10.1080/13504620220145401

Kriwy P., Mecking R.-A. Health and environmental consciousness, costs of behaviour and the purchase of organic food. International Journal of Consumer Studies, 2012, Vol. 36, No. 1. p. 30-37. http://dx.doi.org/10.1111/j.1470-6431.2011.01004.x

Leonavičius V. Profile of contemporary Lithuanian consumer [in Lithuanian]. Sociology, thoughts and action, 2002, Vol. 1. p. 5-15.

Lin P.-C., Huang Y.-H. The influence factors on choice behaviour regarding green products based on the theory of consumption values. Journal of Cleaner Production, 2012, Vol. 22, No. 1. p. 11-18. http://dx.doi.org/10.1016/j.jclepro.2011.10.002

Lynikaitė R., Liesionis V. Research of factors, influencing green products purchase process [in Lithuanian]. Management theory and studies for rural business and infrastructure development, 2010, Vol. 22, No. 3. p. $1-10$
Mazar N., Zhong C. B. Do Green Products Make Us Better People? Psychological Science, 2010, Vol. 21, No. 4. p. $494-498$

http://dx.doi.org/10.1177/0956797610363538

Niaura A. Using the Theory of Planned Behaviour to Investigate the Determinants of Environmental Behaviour among Youth. Environmental Research, Engineering and Management, 2013, Vol. 1, No. 63. p. 74-81.

Park J., Ha S. Understanding pro-environmental behaviour a comparison of sustainable consumers and apathetic consumers. International Journal of Retail \& Distribution Management, 2012, Vol. 40, No. 5. p. 388-403. http://dx.doi.org/10.1108/09590551211222367

Rutkovienė V., Garliauskienė G. Demand of organic products determinants [in Lithuania]. Agricultural sciences, 2007, Vol. 14, No. 2. p. 66-71. ISSN 1392-0200.

Sian F., Chuan S., Kai B., Chen S., Chen B. Culture and Consumer Behaviour: Comparisons between Malays and Chinese in Malaysia. International Journal of Innovation, Management and Technology, 2010, Vol. 1, No. 2. p. $180-185$.

Skulskis V., Girgždienè V. Consumption of organic food products and related information sources in Lithuania [In Lithuanian]. Agricultural sciences, 2009, Vol. 16, No. 34. p. $154-161$

Srinivasan A., Blomquist G.C. Ecolabeled paper towels: consumer valuation and expenditure analysis. Journal of Environmental Management, 2009, Vol. 90. pp. 314 - 320. http://dx.doi.org/10.1016/j.jenvman.2007.09.007

Stankevičienė J. Feasibility of modelling consumer behaviour [In Lithuanian]. Tiltai, 2005, Vol. 2. p. 83-90.

Stašys R., Tarasevičius T. Consumer perception of ecological food product [In Lithuanian]. Management theory and studies for rural business and infrastructure development, 2010, Vol. 20, No. 1. p. 131-137.

Štreimikienė D., Volochovič A., Simanavičienė Ž. Mitigation of climate change impact in households [in Lithuanian]. Power Engineering, 2011, Vol. 57, No. 4. p. 270-281.

Tan B. C., Lau T. C. Examining sustainable consumption patterns of young consumers: is there a cause for concern? The Journal of International Social Research, 2009, Vol. 2, No. 9. p. 465-472.

Tanner C., Kast S. W. Promoting Sustainable Consumption: Determinants of green Purchases by Swiss Consumers. Psychology \& Marketing, 2003, Vol. 20, No. 10. p. 883-902. http://dx.doi.org/10.1002/mar.10101

UN. 2002. 'Johannesburg plan of implementation', New York: United Nations.

UN. 2012. Report of the United Nations Conference on Sustainable Development. Rio de Janeiro, Brazil 20-22 June 2012.

UNEP. 2010. ABC of SCP clarifying concepts in sustainable consumption and production. United Nations Environment Programme, 2010. 
Vermeir I., Verbeke W. Sustainable food consumption among young adults in Belgium: Theory of planned behaviour and the role of confidence and values. Ecological Economics, 2008, Vol. 64, No. 3. p. 542 - 553. http://dx.doi.org/10.1016/j.ecolecon.2007.03.007

Zhu Q., Li Y., Geng Y., Qi Y. Green food consumption intention, behaviours and influencing factors among Chinese consumers. Food Quality and Preference, 2013, Vol. 28. p. 279-286.

http://dx.doi.org/10.1016/j.foodqual.2012.10.005
Dr. Renata DAGILIŪTÉ - lecturer at Department of Environmental Sciences, Vytautas Magnus University, Lithuania.

Main research area: sustainable development, ecoefficiency, sustainable production and consumption

Address: $\quad$ Vileikos str. 8

Tel:: $\quad+37037327904$

E-mail: $\quad$ r.dagiliute@gmf.vdu.lt

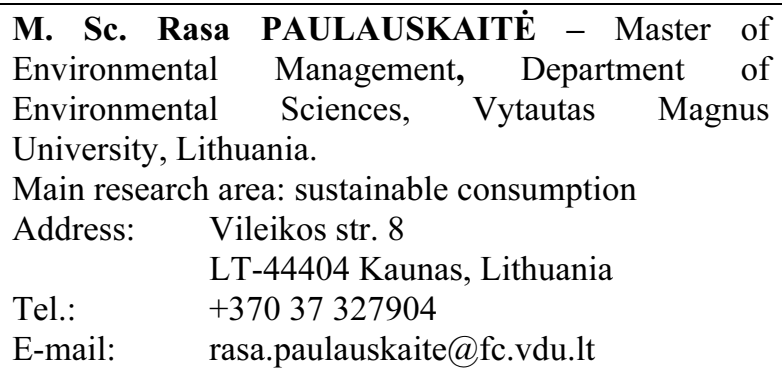

\title{
Ekologiškų produktų pasirinkimas ir jị lemiantys veiksniai: akademinès bendruomenès Lietuvoje atvejis
}

\author{
R. Dagiliūtè, R. Paulauskaitè \\ Vytauto Didžiojo universitetas, Aplinkotyros katedra, Lietuva
}

\section{(gauta 2013 m. liepos mèn., priimta spaudai 2013 m. rugsèjo mèn.)}

Vartojimas turi neigiamą poveikį aplinkai, todèl keisti vartojimo ịpročius ir mažinti apkrovą aplinkai yra vienas iš pagrindinių darniojo vartojimo tikslų. Svarbu skatinti ekologiškų, vietinių produktų rinką. Straipsnyje analizuojamas akademinės bendruomenès pasiryžimas mokèti už produktus ir produktų pasirinkimas atsižvelgiant i jų kainą, kokybę (ekologiškumą) ir kilmę. Apklausos rezultatai parode், kad dauguma respondentų yra pasiryžę rinktis ekologiškus produktus, tačiau kaina tam tikrais atvejais yra lemiantis veiksnys.

Renkantis konkrečius produktus, pirmenybè dažniausiai teikiama ekologiškiems ir (arba) vietiniams produktams. Nepaisant to, tyrimas rodo, kad dar reikia gerinti ir plèsti akademinès bendruomenès švietimą apie produktų ir paslaugų poveikị aplinkai. Persvarsčius ir papildžius studijų programas, vidinę aukštojo mokslo institucijų aplinkosaugos ir(arba) darniojo vystymosi politiką bei veiklas, būtų galima ženkliai prisidèti prie darniojo vartojimo tikslų igyvendinimo. 